\title{
Intoxicação por nitratos e nitritos em bovinos na região semiárida da Paraíba
}

Lisanka Ângelo Maia[a]", Francisco Samiran Bandeira de Morais ${ }^{[a]}$ Gilderlândio Pinheiro Rodrigues ${ }^{[a]}$, Matheus Serafim dos Santos ${ }^{[a]}$, Roberto Alves Bezerra ${ }^{[a]}$, Vinícius Longo Ribeiro Vilela ${ }^{[a]}$, Erick Platiní Ferreira Souto[o ${ }^{[b]}$ Adriana Cunha de Oliveira Assis ${ }^{[b]}$, Robério Gomes Olinda ${ }^{[b]}$, Antônio Flávio Medeiros Dantas ${ }^{[b]}$

\footnotetext{
[a] Medicina Veterinária, Instituto Federal da Paraíba (IFPB), Sousa, PB, Brasil

[b] Programa de Pós-Graduação em Medicina Veterinária, Hospital Veterinário, Centro de Saúde e Tecnologia Rural, Universidade Federal de Campina Grande (UFCG), Patos, PB, Brasil
}

*Autor correspondente

e-mail: lisankavet@hotmail.com

\section{Resumo}

A intoxicação por nitratos e nitritos ocorre principalmente em bovinos e, com menor frequência, em ovinos e caprinos. Essa intoxicação normalmente é observada após a ingestão de forrageiras que acumulam quantidades tóxicas de nitratos/nitritos. Altas concentrações de nitratos nas plantas podem ocorrer no final de prolongado período seco, que causa estresse hídrico nas forrageiras. No entanto, fatores de riscos para acumulação de nitritos são verificados como solo adubado com fertilizantes nitrogenados, adubo orgânico de origem animal ou após a utilização de herbicida 2-4 D, pois favorece o rápido crescimento das plantas. Na região Nordeste, casos de intoxicação por nitratos e nitritos foram relatados em bovinos no estado da Paraíba, associados à ingestão de pastagens de Echynochloa polystachya (capim mandante) ou Pennisetum purpureum (capim elefante) imediatamente após as primeiras chuvas. A intoxicação também foi descrita no Ceará, após a ingestão de P. purpureum, plantado nas margens de um açude que baixou após um ano de seca prolongada, descobrindo as áreas anteriormente cobertas por água, ricas em matéria orgânica. Descreve-se um surto de intoxicação por nitratos e nitritos em bovinos ocorrido em fevereiro de 2017, no município de São José de Piranhas, no semiárido do estado da Paraíba, associado à ingestão de Brachiaria sp. e P. purpureum. As pastagens eram cultivadas em piquetes, divididos em três lotes, sendo que dois destes apresentavam depressões onde acumulava-se água residuária de esgoto doméstico, a qual era utilizada para irrigação das forrageiras. Em um rebanho de 15 bovinos, quatro adoeceram e morreram entre 30 a 90 minutos após a ingestão das pastagens. Os sinais clínicos relatados pelo proprietário foram andar cambaleante, salivação acentuada e dispneia, seguidos de decúbito lateral, timpanismo e morte. Foram 
realizadas necropsias em dois bovinos e, macroscopicamente, observou-se sangue marrom escuro, pulmões e encéfalo com tons amarronzados. Microscopicamente não foram observadas alterações. Amostras de Brachiaria sp. e P. purpureum foram coletadas dos três lotes e submetidas à prova de difenilamina para determinar a presença de nitratos e nitritos. Apenas as amostras dos lotes onde escoavam água residuária com grande quantidade de matéria orgânica apresentaram resultado positivo para nitrato, pela observação de halo coloração azul nas amostras testadas entre 2-3 minutos. Os dados epidemiológicos que indicavam que a enfermidade estava associada ao consumo de forragem, os sinais clínicos característicos com morte hiperaguda, a coloração marrom escura do sangue, associados à positividade da prova da difenilamina nas pastagens, permitiram o diagnóstico da intoxicação por nitratos e nitritos. Acredita-se que a presença de esgoto a céu aberto rico em matéria orgânica irrigando as pastagens contribuiu para o acúmulo de nitratos nas pastagens. É importante ressaltar que essas condições epidemiológicas ainda não foram relatadas em associação à intoxicação por nitratos e nitritos em bovinos. 